\title{
LOAD-BEARING CAPACITY OF SOLID TIMBER BEAMS WITH SMALL CROSS SECTION HEIGHT STRENGTHENED WITH COMPOSITE SHEETS
}

\section{NOŚNOŚĆ NA ZGINANIE LITYCH BELEK O NISKIM PRZEKROJU POPRZECZNYM WZMOCNIONYCH MATAMI KOMPOZYTOWYMI}

DOI: $10.30540 /$ sae-2018-029

\begin{abstract}
The paper presents the results of experimental tests focused on strengthening a solid pine beams with lightweight plastics. Glass fiber reinforced sheets S\&P G-Sheet E 90/10 B and carbon fiber reinforced sheets S\&P C-Sheet 240 applied to the soffit of the element were used as a reinforcement. The four point bending strength test were carried out on the laboratory scale elements. Test results indicated a significant increase in ductile behavior as well as increase in load bearing capacity of beams.
\end{abstract}

Keywords: pine wood, timber structures, glass fibers, carbon fibers, strengthening

Streszczenie

W pracy przedstawione zostały wyniki próby wzmocnienia litych belek sosnowych, wykorzystując lekkie tworzywa sztuczne. Zbrojenie stanowily maty zbrojonej włóknem szklanym $S \& P$ G-Sheet E 90/10 B oraz maty z włóknem węglowym $S \& P$ $C$-Sheet 240 przyklejone do podbitki elementów. Próby te przeprowadzone zostaty na elementach $w$ skali laboratoryjnej poddanych czteropunktowemu zginaniu. Wyniki badań wskazały na istotny wzrost ciagliwości elementów oraz przyrost wytrzymatości na zginanie.

Słowa kluczowe: drewno sosnowe, konstrukcje drewniane, włókna szklane, włókna węglowe, wzmacnianie

\section{INTRODUCTION}

In today's buildings, the demands on the interior finish of the building are increasing.

The first research on the application of composite sheets as a reinforcement of timber structures appeared already in the 1960s. One of the first scientist to made this trials was Theakston, who studied influence of glass fibre reinforced fabrics on load bearing capacity of glulam beams [11]. Further investigations in this sense were undertaken by other researchers in the 1970s and 1980s [1, 12], whose results indicated a potential development of this field. Currently, a large diversification in types of fibers used in laboratory research such as aramid [14], basalt [10], glass, carbon fibres and their hybrids [13] is noticeable.

\section{WPROWADZENIE}

Pierwsze badania nad zastosowaniem tkanin do wzmacniania konstrukcji drewnianych ukazały się już w latach 60. ubiegłego wieku. Jednym z pierwszych naukowców wykonujących te próby był Theakston, który badał wpływ tkanin zbrojonych włóknem szklanym oraz typu kleju na nośność belek z drewna klejonego warstwowo [11]. Prace w tym kierunku podjęte zostały także przez innych badaczy w latach 70. i 80. [1, 12], a ich wyniki wskazały na istniejący potencjał rozwoju tej dziedziny. Obecnie występuje duże zdywersyfikowanie $\mathrm{w}$ stosowanych $\mathrm{w}$ badaniach laboratoryjnych rodzajach włókien, do których zaliczyć można włókna: aramidowe [14], bazaltowe [10], szklane, węglowe, a także ich hybrydy [13]. 
The most common fibre reinforced composites are laminates [2, 5], rods [4] and fabrics [3, 6].

Fabrics for strengthening structures are manufactured as uni- or bidirectional reinforced sheets. Major advantages, which opt in favor of using these materials to strengthen wooden structures, are as follows: low density, high tensile strength, high stiffness, corrosion resistance and flexibility.

\section{MATERIALS AND METHODOLOGY}

\subsection{Timber}

Pine wood beams was used in preliminary research. The grade class assessed by visual method was C24 [8]. The cross section of the beam was $80 \times 80 \mathrm{~mm}$. The total length of the beam was $1.6 \mathrm{~m}$ with a clear span of $1.44 \mathrm{~m}$.

\subsection{FRP sheets}

Glass fiber reinforced polymer sheets S\&P G-Sheet E 90/10 B and carbon fiber polymer sheets S\&P C-Sheet 240 were used as a reinforcement. Selected material properties of sheets are shown in Table 1.

\begin{tabular}{|l|c|c|}
\hline Parameter & $\begin{array}{c}\text { Glass sheets } \\
\text { S\&P G-Sheet E } \\
\mathbf{9 0 / 1 0 ~ B ~}\end{array}$ & $\begin{array}{c}\text { Carbon sheets } \\
\text { S\&P C-Sheet 240 } \\
\mathbf{6 0 0 ~} \mathbf{g} / \mathbf{m}^{\mathbf{2}}\end{array}$ \\
\hline Elastic modulus $\left[\mathrm{kN} / \mathrm{mm}^{2}\right]$ & $\geq 73$ & $\geq 265$ \\
\hline Tensile strength $\left[\mathrm{N} / \mathrm{mm}^{2}\right]$ & $\geq 3400$ & $\geq 5100$ \\
\hline Fibre weight - longitudinal $\left[\mathrm{g} / \mathrm{m}^{2}\right]$ & 800 & 600 \\
\hline Weight per unit area of sheet $\left[\mathrm{g} / \mathrm{m}^{2}\right]$ & 880 & 630 \\
\hline Density $\left[\mathrm{g} / \mathrm{cm}^{2}\right]$ & 2.60 & 1.80 \\
\hline Elongation at rupture $[\%]$ & 4.5 & $\geq 1.7 \div 1.9$ \\
\hline Design thickness $[\mathrm{mm}]$ & 0.308 & 0.333 \\
\hline
\end{tabular}

\subsection{Adhesive}

Two component S\&P Resin 55 epoxy resin adhesive, mixed with 2:1 ratio, was used to apply on the beam surface and composite sheet in order to obtain proper bonding. Surface of the elements was grinded and cleaned before the application of adhesive. Modulus of elasticity and elongation at break, according to manufacturer data sheets [4], are $3200 \mathrm{MPa}$ and $1.73 \%$, respectively.

\subsection{Experimental program}

The tests were conducted at the Laboratory for the Strength of Materials of the Kielce University of Technology.
Najpopularniejszymi rodzajami kompozytów FRP są laminaty [2, 5], pręty [4] oraz tkaniny $[3,6]$.

Tkaniny do wzmacniania konstrukcji produkowane są w postaci jedno- bądź wielokierunkowych zbrojonych mat. Decydującymi zaletami przemawiającymi za zastosowaniem ich do wzmacniania konstrukcji drewnianych są: mały ciężar własny, wysoka wytrzymałość na rozciąganie, wysoka sztywność, odporność na korozję i elastyczność.

\section{MATERIAŁY I METODOLOGIA}

\subsection{Drewno}

Belki z drewna sosnowego wykorzystano w badaniach wstępnych. Klasa drewna na podstawie sortowania wizualnego określona została jako C24 [7]. Przekrój poprzeczny belek przyjęto o wymiarach 80 x $80 \mathrm{~mm}$. Długość całkowita belek wynosiła 1,6 m, a w świetle podpór $1,44 \mathrm{~m}$.

\subsection{Maty kompozytowe}

W badaniach wykorzystano maty zbrojone włóknem szklanym S\&P G-Sheet E 90/10 B oraz maty zbrojone włóknem węglowym S\&P C-Sheet 240. Wybrane parametry techniczne mat przedstawione zostały w tabeli 1 .

Table 1. Selected material properties of applied composite sheets [4]

Tabela 1. Wybrane właściwości materialowe zastosowanych mat kompozytowych [4]

\subsection{Klej}

Do aplikacji zbrojenia zastosowany dwuskładnikowy klej na bazie żywicy epoksydowej S\&P Resin 55, wymieszane w proporcjach 2:1. By uzyskać właściwe połączenie mieszanka nałożona została na powierzchnię drewna i matę kompozytową. Przed aplikacją powierzchnia elementów została wyszlifowana i oczyszczona. Zgodnie z kartami technicznymi producenta moduł sprężystości oraz wydłużenie przy zniszczeniu kleju wynoszą odpowiednio $3200 \mathrm{MPa}$ i 1,73\% [4].

\subsection{Program eksperymentu}

Badania przeprowadzone zostały w Laboratorium Wytrzymałości Materiałów Politechniki Świętokrzyskiej w Kielcach. 
The subject of the own research was analysis of static work of solid pine beams strengthened with composite sheets bonded to the external surface of elements. Analysis involved strengthening tensile zone of bent elements by applying one layer of sheet reinforced with glass fibers S\&P G-Sheet E 90/10 B and sheet reinforced with carbon fiber S\&P C-Sheet 240. Sheets were applied along the entire length of beams. For this purpose three series of elements was prepared (three elements in each series), as follows:

- BD - reference beams,

- BDG - beams strengthened with glass sheets,

- BDC - beams strengthened with carbon sheets.

The four point bending test static scheme setup is shown on Figure 1. The bending strength tests were carried out with accordance to [8].
Przedmiotem badań własnych była analiza pracy statycznej litych belek sosnowych o wzmocnionych matami kompozytowymi przyklejanymi do zewnętrznych powierzchni elementów. Analiza ta uwzględniała wzmocnienie strefy rozciąganej elementów zginanych poprzez doklejenie na całej jej długości jednej warstwy maty zbrojonej włóknem szklanym S\&P G-Sheet E 90/10 B oraz maty z włóknem węglowym S\&P C-Sheet 240 . W tym celu przygotowane zostały trzy serie próbek (trzy elementy w każdej):

- BD - belki referencyjne,

- BDG - belki wzmocnione matami szklanymi,

- BDC - belki wzmocnione matami węglowymi.

Do badań przyjęto schemat statyczny tzw. „czteropunktowego" zginania przedstawiony na rysunku 1 . Próby wytrzymałości na zginanie wykonano według zaleceń normy [8].

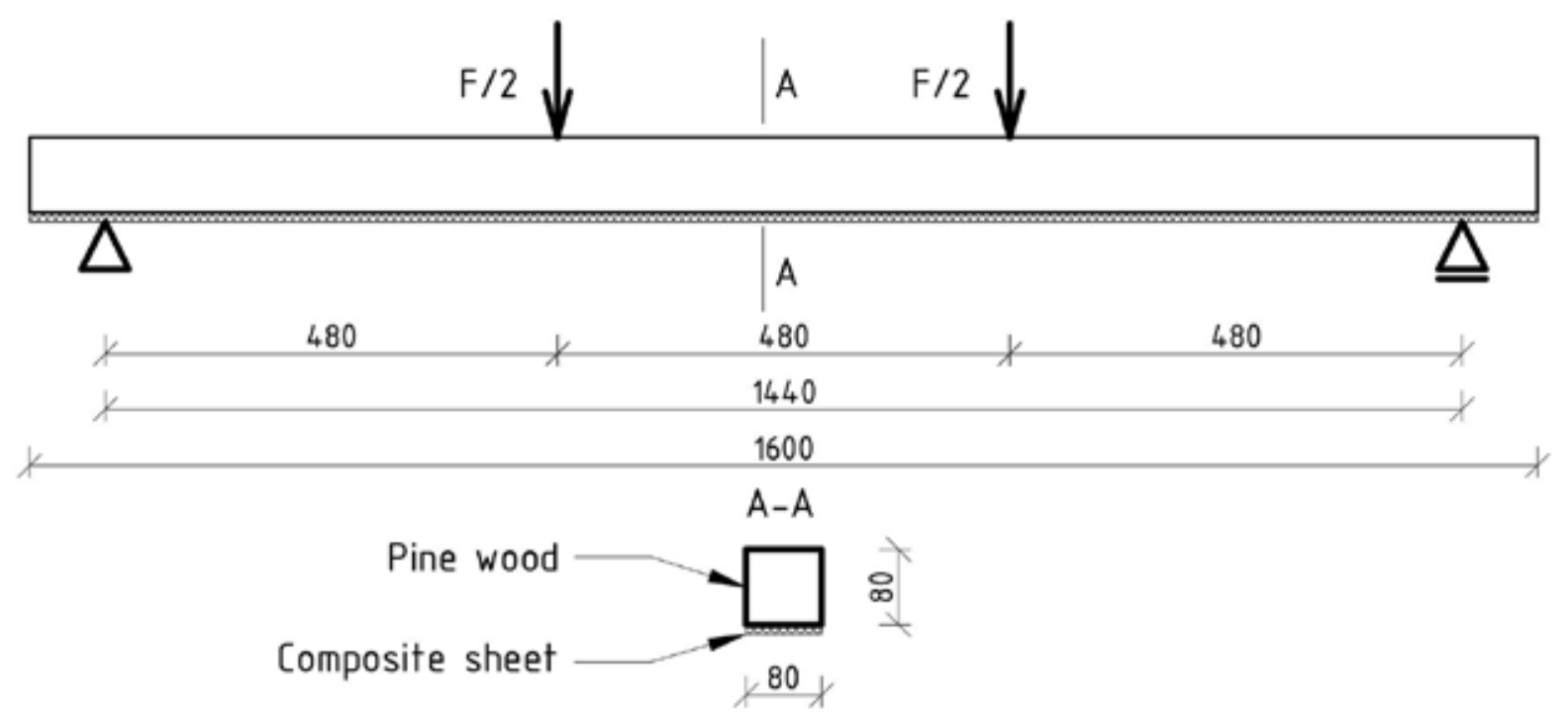

Fig. 1. Scheme of the static test setup

Rys. 1. Schemat stanowiska badawczego

Hydraulic universal testing machine MTS-322 was used for bending strength tests. The loading rate of an actuator was set to $7 \mathrm{~mm} / \mathrm{min}$. The loading force, test time and displacement of actuator were continuously measured during tests. Frequency measurement was set to $5 \mathrm{~Hz}$. After the static tests, documentation of failure mode was created and the moisture content of all the specimens was checked using a TANEL WRD-100.

The bending strength $f_{m}$ was determined on the basis of the test results from the following equation [8]:

$$
f_{m}=\frac{3 F a}{b h^{2}}
$$

W badaniach wykorzystano uniwersalną maszynę wytrzymałościową MTS-322, z ustaloną prędkością przesuwu napór obciążających równą $7 \mathrm{~mm} / \mathrm{min}$. W trakcie badań w sposób ciągły rejestrowano siłę obciążającą, czas badania oraz przemieszczenie napór. Częstotliwość rejestracji tych pomiarów przyjęto równą $5 \mathrm{~Hz}$. Po przeprowadzonych badaniach udokumentowano postać zniszczenia oraz skontrolowano wilgotność wszystkich próbek za pomocą wilgotnościomierza WRD-100 firmy TANEL.

Na podstawie uzyskanych wyników badań wartość wytrzymałości na zginanie $f_{m}$ oszacowana została według wzoru [8]:

$$
f_{m}=\frac{3 F a}{b h^{2}}
$$


where:

$a$ - distance between a loading position and the nearest support, in millimeters;

$F$ - loading force, in newtons;

$b$ - width of cross section, in millimeters;

$h$-height of cross section, in millimeters.

\section{EXPERIMENTAL RESULTS}

Figure 2 shows the relationship between the loading force and displacement in the axis of loading force for tested elements. On the diagram three groups of elements are presented, including reference beams marked with BD symbol, and two groups of strengthened elements: BDG - beams strengthened with GFRP sheets and BDC - beams strengthened with CFRP sheets. Each group consist of three elements. In the case of unstrengthened beams, curves indicates almost linear behavior through the entire range of tests. Deviation of the course of individual curves are sporadically visible for these specimens. Beams strengthened with glass fiber reinforced polymer sheets are characterized by the longest time of the test what is equivalent to the longest plastic range of work for each specimen. The transition into non-linear range of work took place quite early and caused flattening of each curve. There are also numerous faults, especially in the final phase of the research, resulting from the propagation of the crack perpendicular to the fibers in the axis of loading forces. Failure of these elements occurred in steps, until final destruction. Last type of specimens obtained the greatest increase in load-bearing capacity. However, it was also characterized by the biggest discrepancies in time to destruction of different elements in the group. These differences was caused by heterogeneity identified with defects in wood specimens.

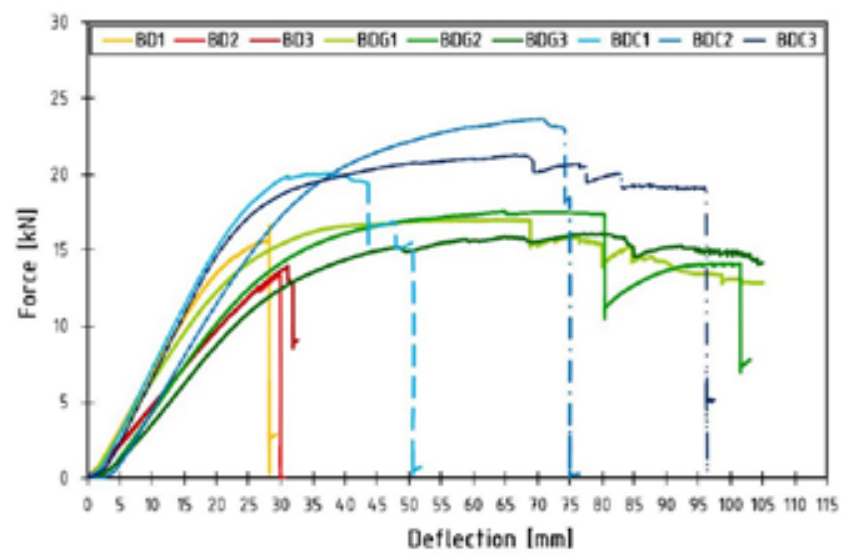

w którym:

$a$ - odległość od punktu przyłożenia siły skupionej do osi najbliższej podpory, w milimetrach;

$F$ - wartość siły obciążającej, w niutonach;

$b$ - wymiary przekroju poprzecznego, w milimetrach; $h$-wymiary przekroju poprzecznego, w milimetrach.

\section{REZULTATY BADAŃ}

Rysunek 2 przedstawia wykres zależności pomiędzy siłą obciążającą element a przemieszczeniem w osiach napór obciążających elementów. Na wykresie widoczne są trzy grupy elementów, belki referencyjne oznaczone symbolem BD oraz dwie grupy belek wzmocnionych: BDG - belki wzmocnione matami szklanymi i BDC - belki wzmocnione matami węglowymi. Każda z grup zawiera trzy elementy. W przypadku belek niewzmocnionych krzywe wskazują na niemal liniową zależność przez cały zakres badania. Sporadycznie widoczne są skoki w przebiegu poszczególnych krzywych. Belki wzmocnione matami szklanymi charakteryzowały się najdłuższym czasem badania, równoważnym $\mathrm{z}$ najdłuższym zakresem pracy niesprężystej elementu. Przejście belek w nieliniowy zakres pracy następowało dość wcześnie i powodowało spłaszczenie wykresu. Widoczne są także liczne uskoki, szczególnie w końcowej fazie badania, będących następstwem propagacji pęknięcia prostopadłego do włókien w osi napór obciążających. Zniszczenie tych elementów następowało skokowo. Ostatni typ elementów uzyskał największy przyrost nośności, jednak charakteryzował się największymi rozbieżnościami w czasie do zniszczenia próbki. Spowodowały to niejednorodności pierwszego rodzaju elementów utożsamiane z wadami materiałowymi.

Fig. 2. Load-deflection curves of tested elements Rys. 2. Krzywe obciążenia i ugięcia badanych elementów 
Failure of the unstrengthened beams occurred in the maximum bending moment zone. It was caused by exceeding the tensile strength in wood fibers (Fig. 3).

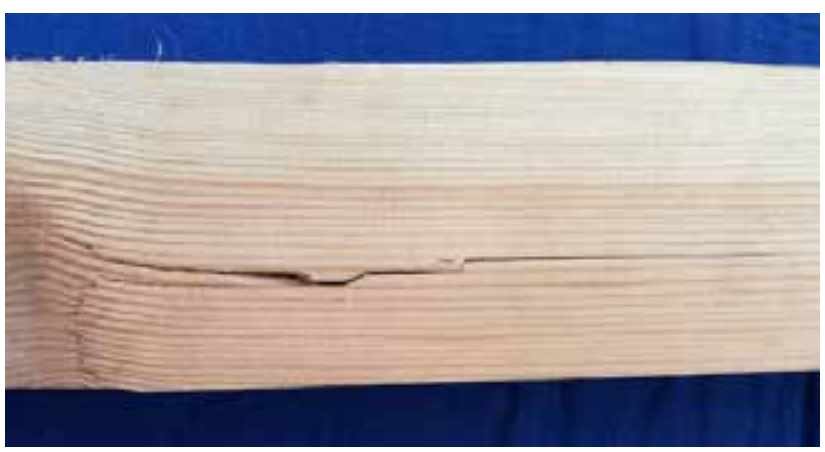

Figure 4 shows typical failure of specimens strengthened with carbon fiber reinforced polymer sheets which consisted of failure occurred in compression zone caused by exceeding compression strength perpendicular to the wood fibers and the shear failure along the wood fibers. In the final phase of the test the rupture of carbon fibers occurred.
Zniszczenie belek niewzmocnionych następowało w miejscu występowania maksymalnego momentu zginającego. Spowodowane było przekroczeniem wytrzymałości na rozciąganie w skrajnych włóknach dolnych (rys. 3).

Fig. 3. Typical failure mode of reference beams Rys. 3. Typowa postać zniszczenia belek referencyjnych

Na rysunku 4 przedstawiono typowe zniszczenie belek wzmocnionych matami zbrojonymi włóknem węglowym. Składało się ono ze zniszczenia w strefie ściskanej, wynikającego z przekroczenia nośności na ściskanie prostopadle do włókien drewna oraz ścięcia wzdłuż włókien w strefie przypodporowej. W końcowej fazie badania nastąpiło przerwanie ciągłości tkaniny równoległe do kierunku głównego maty.
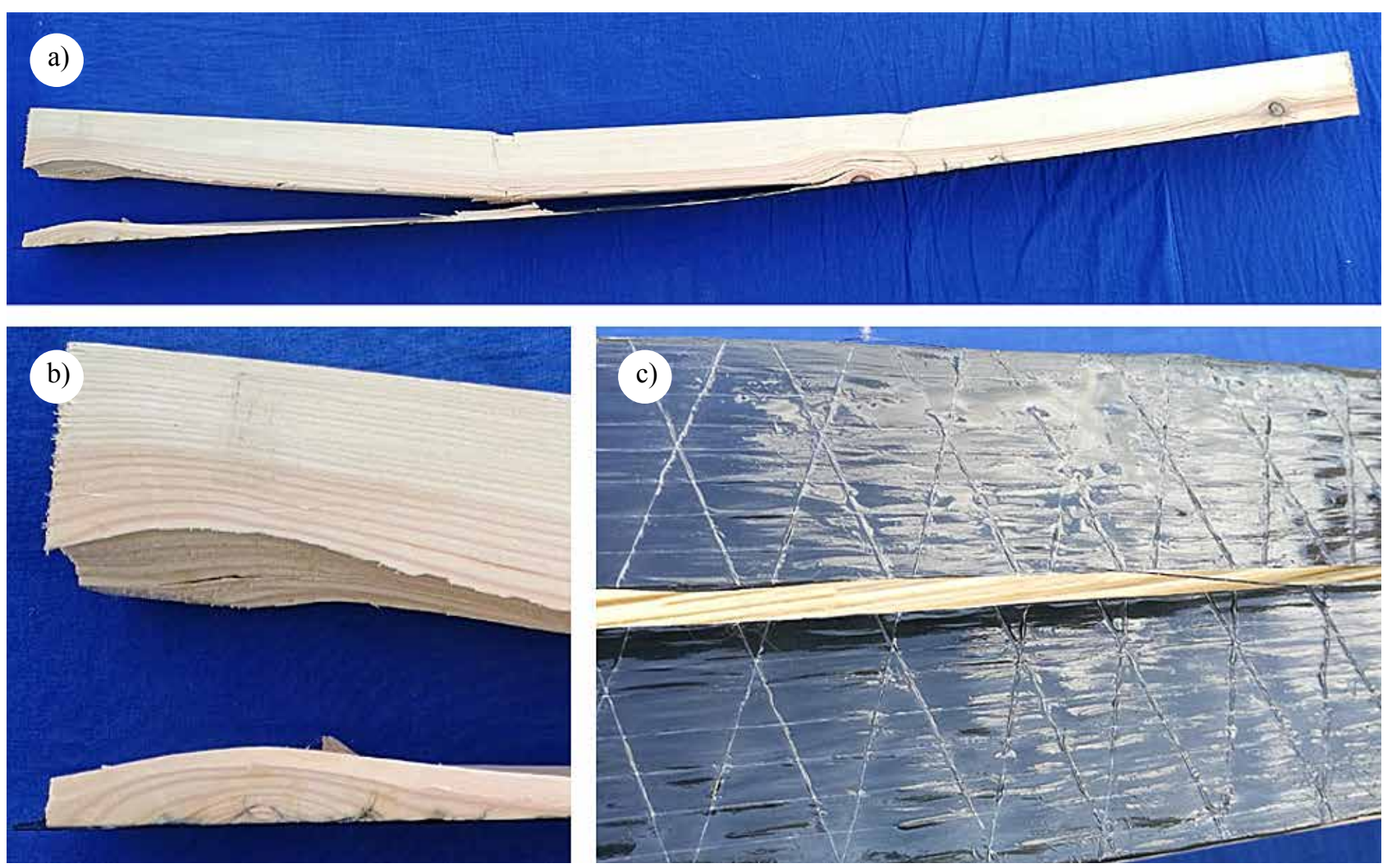

Fig. 4. Failure mode of element strengthened with CFRP sheet: a) general view, b) shear failure, c) rupture along composite material

Rys. 4. Zniszczenie belek wzmocnionych włóknem węglowym: a) widok ogólny, b) zniszczenie wywołane ścinaniem, c) pęknięcie wzdluż kompozytu 
In the case of beams strengthened with glass fiber reinforced sheets, the analogy in the failure mode to the beams strengthened with CFRP sheets is visible. However, due to the lower value of the loading force, the failure had a gentler character. Propagation of the crack in the axis of concentrated force was accompanied by slow rupture of glass fibers (Fig. 5).
W przypadku belek wzmocnionych matami szklanymi można dostrzec analogię $\mathrm{w}$ zniszczeniu belek wzmocnionych matami węglowymi. Jednak z uwagi na mniejszą wartość siły obciążającej miało ono łagodniejszy przebieg. Propagacji pęknięcia w osi napór obciążających towarzyszyło powolne przerywanie włókien szklanych (rys. 5).
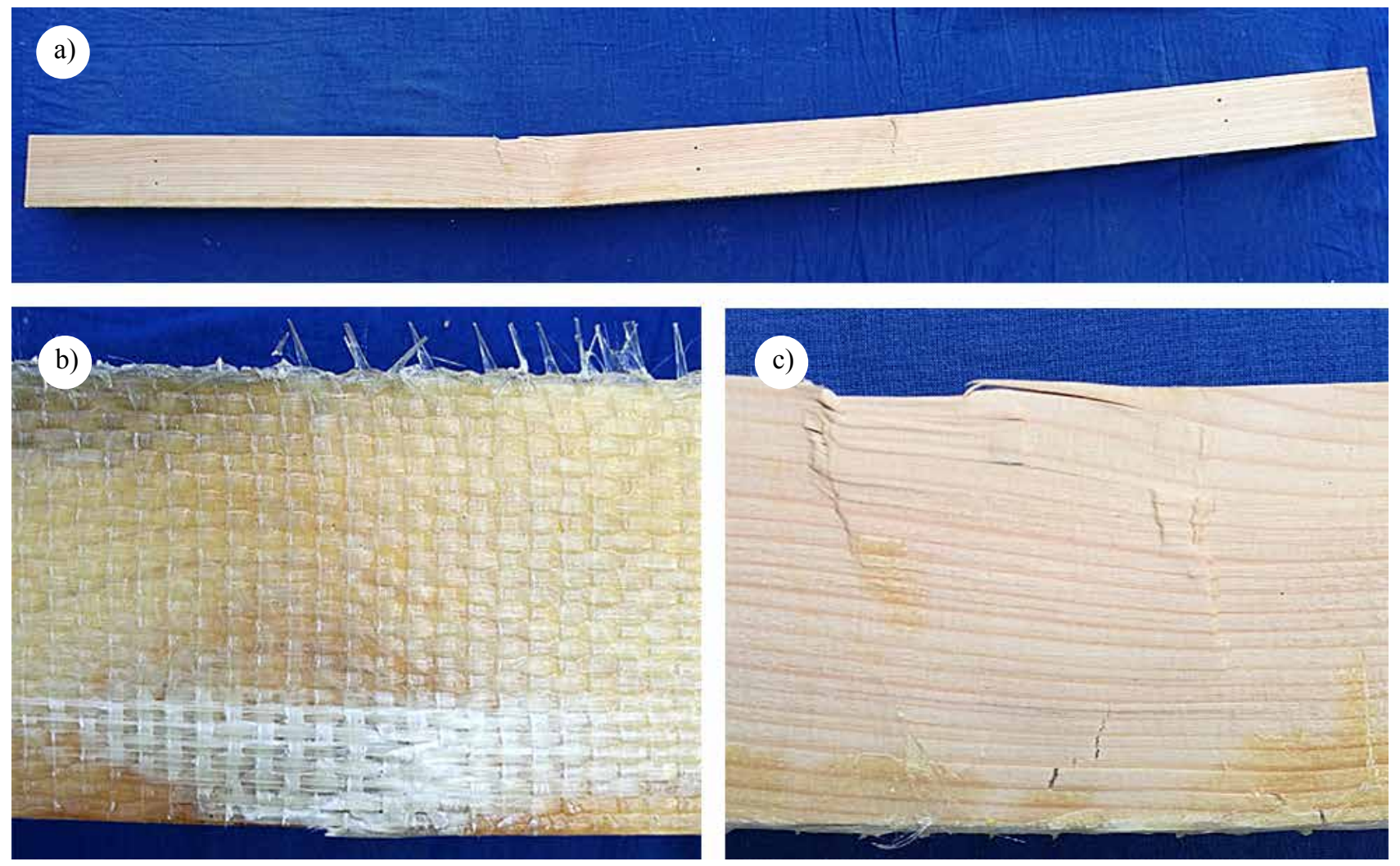

Fig. 5. Failure mode of element strengthened with GFRP sheet: a) general view, b) rupture of GFRP sheet, c) crack propagation in the concentrated force axis

Rys. 5. Zniszczenie belek wzmocnionych włóknem szklanym: a) widok ogólny, b) przerwanie maty, c) propagacja pęknięcia w osi napór obciażajacych

The results of the four-point bending tests are shown in Table 2 . Table provides the values of the failure load, the maximum bending moment, bending strength, test time and deflection.

The average increase of bending strength for beams strengthened with glass and carbon sheets was $15 \%$ and $48 \%$, respectively. Significant increase in ductile behavior of strengthened beams was noted for both types of fibers. The growth in deflection at the maximum force was over $200 \%$ in comparison to the reference beams.

The moisture content of elements was $12-16 \%$.
Zestawienie wyników badań uwzględniające wartości siły niszczącej, maksymalny moment zginający, wytrzymałość na zginanie, czas badania oraz ugięcie elementów przedstawione zostało w tabeli 2 .

Wzrost wytrzymałości na zginanie $\mathrm{w}$ przypadku belek wzmocnionych matami szklanymi wyniósł $15 \%$, a przy zastosowaniu mat węglowych wynosił on $48 \%$. Dla obu rodzajów włókien istotny wzrost ciągliwości elementów został odnotowany. Przyrost ugięcia przy maksymalnej sile wyniósł ponad 200\% w stosunku do belek referencyjnych.

Wilgotność próbek wynosiła 12-16\%. 
Table 2. Test results

Tabela 2. Wyniki badań

\begin{tabular}{|c|c|c|c|}
\hline Parameter & Reference beams & $\begin{array}{l}\text { Beams strengthened } \\
\text { with GFRP sheets }\end{array}$ & $\begin{array}{l}\text { Beams strengthened } \\
\text { with CFRP sheets }\end{array}$ \\
\hline Maximum concentrated force [kN] & 14.61 & 16.85 & 21.66 \\
\hline Maximum bending moment [kNm] & 3.51 & 4.04 & 5.20 \\
\hline Bending strength [MPa] & 41.10 & $47.38(+15 \%)$ & $60.93(+48 \%)$ \\
\hline $\begin{array}{l}\text { Deflection corresponding to the maximum concentrated } \\
\text { force [mm] }\end{array}$ & 29.72 & $68.84(+232 \%)$ & $75.25(+252 \%)$ \\
\hline Time to failure $[\mathrm{s}]$ & 254 & 590 & 645 \\
\hline
\end{tabular}

\section{SUMMARY}

The subject of the tests was analysis of the static work of pine beams with small cross section height strengthened with composite sheets. Glass and carbon fiber reinforced polymer sheets were used as reinforcement.

The results of the preliminary tests carried out showed that strengthening the tensile zone with composite fabrics contributed primarily to the increase of the load-bearing capacity of the beams. The increase in the case of a group of beams reinforced with glass sheets was $15 \%$ and $48 \%$ in the case of using carbon sheets. In addition, a significant increase in deflection and duration test should be noted for both types of fibers. Therefore, it can be concluded that composite sheets are a beneficial solution for strengthening beams and other bent elements.

\section{PODSUMOWANIE}

Przedmiotem badań była analiza pracy statycznej sosnowych belek o niskim przekroju wzmocnionych matami kompozytowymi. Jako wzmocnienie zastosowano maty zbrojone włóknem szklanym i węglowym.

Wyniki przeprowadzonych badań wstępnych wskazują, że wzmocnienie strefy rozciąganej za pomocą tkanin kompozytowych wpłynęło przede wszystkim na wzrost nośności belek. Wzrost nośności dla belek wzmocnionych matami szklanymi wyniósł $15 \%$ oraz $48 \% \mathrm{w}$ przypadku zastosowania mat węglowych, dla których jednocześnie odnotowano istotny przyrost modułu sprężystości przy zginaniu. Oprócz tego dla obu typów włókien stwierdzono istotny przyrost ugięcia oraz czasu trwania do zniszczenia. Można zatem stwierdzić, że maty kompozytowe stanowią korzystne rozwiązanie w przypadku wzmacniania belek oraz innych elementów zginanych.

\section{REFERENCES}

[1] Biblis E.J.: Analysis of wood-fibreglass composite beams within and beyond the elastic region. Forest Products Journal 15 (2), 1965, pp. 81-88.

[2] De Jesus A.M.P., Pinto J.M.T., Morais,J.J.L.: Analysis of solid wood beams strengthened with CFRP laminates of distinct lengths. Construction and Building Materials 35, 2012, pp. 817-828.

[3] Gezer H., Aydemir B.: The effect of the wrapped carbon fibre reinforced polymer material on fire and pine woods. Materials and Desing 31, 2010, pp. 3564-3567.

[4] http://www.sp-reinforcement.pl/pl-PL

[5] Li Y-F., Tsai M-J., Wei T-F., Wang W-C.: A study on wood beams strengthened by FRP composite materials. Construction and Building Materials 62, 2014, pp. 118-125.

[6] Nowak T.: Wzmacnianie drewnianych konstrukcji zabytkowych przy użyciu taśm węglowych. Wiadomości Konserwatorskie 14, 2003, pp. 21-27.

[7] Kossakowski P.: Load-bearing capacity of wooden beams reinforced with composite sheets (Nośność belek drewnianych wzmocnionych matami kompozytowymi). Structure \& Environment, 3 (4), 2011, pp. 14-22.

[8] PN-EN 338:2016-06 Structural timber. Strength classes.

[9] PN-EN 408+A1:2012 Timber structures. Structural timber and glued laminated timber. Determination of some physical and mechanical properties.

[10] Raftery G.M., Kelly F.: Basalt FRP rods for reinforcement and repair of timber. Composites: Part B 70, 2015, pp. 9-19.

[11] Theakston F.H.: A feasibility study for strengthening timber beams with fibre glass. Canadian Agricultural Engineering, January, 1965, pp. 17-19. 
[12] Wangaard F.F.: Elastic deflection of wood-fiberglass composite beams. Forest Products Journal 14(6), 1964, pp. 256-260.

[13] Yang Y-L., Liu J-W., Xiong G-J.: Flexural behavior of wood beams strengthened with HFRP. Construction and Building Materials 43, 2013, pp. 118-124.

[14] Yahyaei-Moayyed M., Taheri F.: Experimental and computational investigations into creep response of AFRP reinforced timber beams. Composite Structures 93 (2), 2011, pp. 616-628.

\section{Acknowledgments:}

This work was supported by Kielce University of Technology, statutory work No. 02.0.06.00/2.01.01.02.0000, MNSC. BKWB.18.002. The authors wish to thank S\&P Polska Sp. $z$ o.o. company for provided research materials.

\section{Podziękowania:}

Praca powstała dzięki wsparciu finansowemu Politechniki Świętokrzyskiej w ramach pracy statutowej nr 02.0.06.00/2.01.01.02.0000, MNSC.BKWB.18.002. Autorzy pragna również podziękować firmie S\&P Polska Sp. z o.o. za przekazane materiaty do badań. 